\title{
Návrat ke kořenům evropské slavistiky. Slovinské sympózium o Matiji Murkovi
}

\author{
Miloš Zelenka (České Budějovice)
}

Ve dnech 3.-4. 6. 2019 se v hlavní budově Slovinské akademie věd a umění na Novém náměstí v Lublani konalo sympózium pod názvem Matija Murko - slovanski filolog v najširšem pomenu besede. Slovinský návrat pravděpodobně k poslednímu komplexnímu klasiku slovanské filologie signalizoval zvýšený zájem o klíčovou osobnost evropské lingvistiky, literární vědy a folkloristiky pohybující se po ruských a středoevropských univerzitách. Murkovo dědictví už nevzbuzuje dojem antikvárního monolitu zakotveného v pozitivistické metodologii či nereprezentuje jen výrazný symbol jugoslávství, který v rámci ideologické jednoty vystupuje proti národní filologii rozvíjené po roce 1918 v slovinském prostředí F. Ramovšem, F. Kidrićem, K. Štrekeljem, I. Prijateljem ad. Lze tudíž ocenit, že čeští slavisté od dob J. Polívky, J. Vlčka, J. Máchala ad. přes F. Wollmana až po S. Wollmana, A. Měštana, I. Pospíšila ad. se k Murkovi pozitivně hlásili už jen tím, že systematicky poukazovali na jeho organizační aktivity, metodickou spjatost s materiálem, široký kulturněhistorický a filologický záběr, resp. na komparativní schopnost spojovat protikladné jevy a nazírat větší meziliterární celky v kontextových souvislostech. Česká slavistika se rovněž může prokázat dvěma murkovskými publikacemi vznikajícími v mezinárodní spolupráci: Murkova epocha slovanské filologie (ed. M. Zelenka, Praha, 2003) a Matija Murko v myšlenkovém kontextu europské slavistiky (eds. I. Pospísil - M. Zelenka, Brno, 2005).

Hlavní organizátor konference, mariborský badatel Marko Jesenšek, vytyčil tematické okruhy, které si kladly za cíl Murka nejen nově ukázat v evropském rozměru, ale prezentovat i jeho přínos pro jednotlivé disciplíny, a především pro slovinskou národní literární vědu, lingvistiku a folkloristiku. Na konferenci zazněly zhruba dvě desítky referátů přednesených badateli z šesti zemí (Anglie, Černá Hora, Česká republika, Chorvatsko, Rakousko a Slovinsko, zástupce polské literární vědy se osobně nedostavil, ale poslal abstrakt), které se soustředily k rozmanitým otázkám Murkovy biografie a jeho díla. Zaměřily se především na odhalení etymologického původu badatelova příjmení (M. Snoj), na výzkumy srbské a chorvatské lidové epiky v souvislosti s metodologickou anticipací tzv. teorie „oral poetry“ (K. Gantar) a tezí amerického etnologa Milmana Parryho (B. Zabel), dále na studentská léta na Vídeňské univerzitě (G. Neweklowsky) či na jeho vědecké začátky ve Štýrském Hradci (A. Golob). Murka jako posledního vědeckého romantika a Miklošičova pokračovatele vyzdvihl ve svém zajímavém příspěvku lublaňský historik Igor Grdina. Autor těchto řádků ve společném referátu (s I. Pospíśilem) prezentoval česko-slovinské projekty, zabývající se Murkem jako interdisciplinárním komparatistou předjímajícím dnes moderní spojení filologie se sociálními vědami v tzv. areálových studiích (area studies). Obdobně lublaňská folkloristka Marija Stanonik se vrátila $\mathrm{k}$ předchozím projektům, které připomněly Murkovy etnologické zásluhy pro slovinskou kulturněhistorickou etnologii. Velkou pozornost, jak jsme již zdůraznili, vzbuzovaly badatelovy výzkumy jihoslovanské epiky (H. M. Lausseggerová, N. Vujović) a srbochorvatského reformačního hnutí (I. Eterović, V. Rajšp). V této souvislosti Drago Kunej ocenil Murkovu dnes již klasickou monografii Tragom srpsko-hrvatske narodne epike (1951) jako vzor pro dokumentování etnomuzikologických terénních výzkumů. Obdobně Jože Hudales vyzdvihl badatelův podíl na založení slovinského muzejnictví pod vlivem osobní návštěvy Českoslovanské národopisné výstavy v roce 1895 . Časté byly i reflexe Murkovy komplexní filologické osobnosti jako interdisciplinárního typu rozkročeného 
mezi středoevropský a ryze nacionální slovinský kontext (I. Slavec Gradišnik, M. Golež Kaučič, H. Tivadar). Nechyběl také pohled na badatelovu rozsáhlou, v celistvosti dosud nevydanou a kriticky nezhodnocenou korespondenci, uloženou v evropských a ruských archivech. Tento heuristický př́stup představil Marko Jesenšek, který interpretoval Murkovy dopisy Jagićovi z let 1887-1923. Nebylo však rozlišeno, které dopisy byly už vydány a které byly nyní nalezeny. Konference tematicky ani neopominula badatelovy rané lingvistické studie, jimž se objevně věnovala, a to zejména v souvislosti s teorií př́klonek ve slovinštině, Andreja Žele.

Celkově konference splatila v slovinské humanistice dlouholetý dluh této renesanční osobnosti moderní slovanské filologie. Řada badatelských okruhů, např. rozměr Murka jako politicky veřejné osobnosti včetně nezmapované korespondence či jeho složitý vztah k moderním -ismům, však zůstala nedotčena. Často se opakovaly příspěvky „nově objevující známá fakta a souvislosti: tomu bylo možné čelit pouhým nahlédnutím do slavistovy bibliografie obsažené v publikaci Murkova epocha slovanské filologie (bibliografie M. Murka od J. Bečky a A. Zelenkové). Třeba však zdůraznit, že již pouhé připomenutí myšlenkových okruhů, které badatel synekdochicky ztělesňuje, může být v odlišných souvislostech či v kontextových aktualizacích př́nosné pro současnou slavistiku pertraktovanou jako oborově otevřenou disciplínu „na křižovatce“.

\section{prof. PhDr. Miloš Zelenka, DrSc.}

Katedra slovanských jazyků a literatur

Pedagogická fakulta, Jihočeská univerzita

Jeronýmova 10, 37115 České Budějovice, Česká republika

zelenka@pf.jcu.cz 